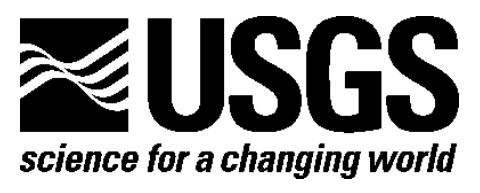

\title{
Soil Data for a Vegetation Gradient Located at Bonanza Creek Long Term Ecological Research Site, Interior Alaska
}

By Kristen L. Manies, Jennifer W. Harden, Christopher C. Fuller, Xiaomei Xu, and John P. McGeehin

Open-File Report 2016-1034

U.S. Department of the Interior

U.S. Geological Survey 


\section{U.S. Department of the Interior \\ SALLY JEWELL, Secretary}

\section{U.S. Geological Survey \\ Suzette M. Kimball, Director}

U.S. Geological Survey, Reston, Virginia: 2016

For more information on the USGS—-the Federal source for science about the Earth, its natural and living resources, natural hazards, and the environment-visit http://www.usgs.gov/ or call 1-888-ASK-USGS (1-888-275-8747).

For an overview of USGS information products, including maps, imagery, and publications, visit http://www.usgs.gov/pubprod/.

Any use of trade, firm, or product names is for descriptive purposes only and does not imply endorsement by the U.S. Government.

Although this information product, for the most part, is in the public domain, it also may contain copyrighted materials as noted in the text. Permission to reproduce copyrighted items must be secured from the copyright owner.

\section{Suggested citation:}

Manies, K.L., Harden, J.W., Fuller, C.C., Xu, X., and McGeehin, J.P., 2016, Soil data for a vegetation gradient located at Bonanza Creek Long Term Ecological Research Site, interior Alaska: U.S. Geological Survey Open-File Report 2016-1034, 10 p., http://dx.doi.org/10.3133/ofr20161034. 


\section{Contents}

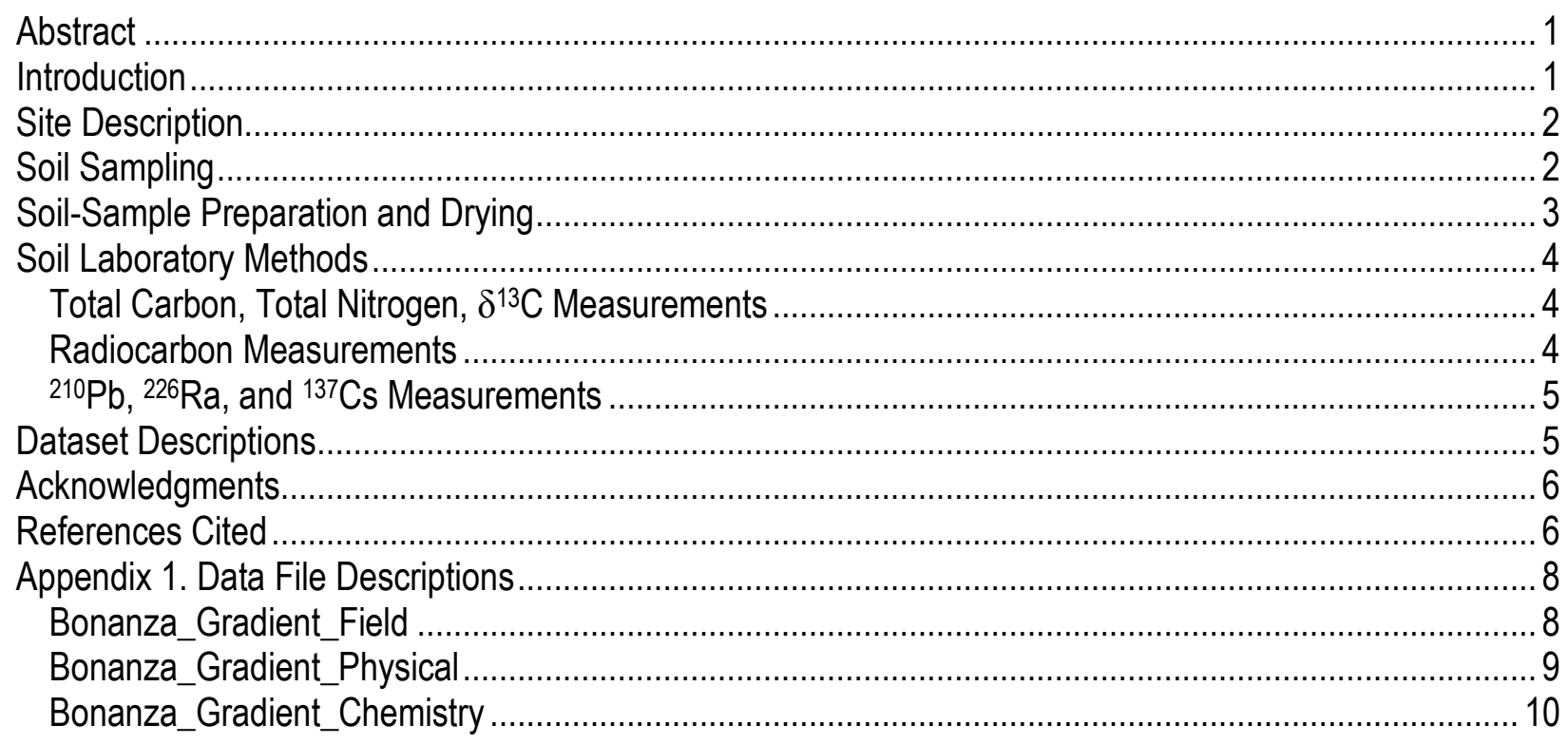

\section{Tables}

1. Statistics of analyses for working standards run on the Carlo Erba 1500, from 2006-2010 ........... 4 


\section{Conversion Factors}

International System of Units to U.S. customary units

\begin{tabular}{|c|c|c|}
\hline Multiply & By & To obtain \\
\hline \multicolumn{3}{|c|}{ Length } \\
\hline centimeter $(\mathrm{cm})$ & 0.3937 & inch (in.) \\
\hline millimeter $(\mathrm{mm})$ & 0.03937 & inch (in.) \\
\hline meter $(\mathrm{m})$ & 3.281 & foot (ft) \\
\hline meter (m) & 1.094 & yard (yd) \\
\hline \multicolumn{3}{|c|}{ Area } \\
\hline square meter $\left(\mathrm{m}^{2}\right)$ & 10.76 & square foot $\left(\mathrm{ft}^{2}\right)$ \\
\hline \multicolumn{3}{|c|}{ Mass } \\
\hline $\operatorname{gram}(\mathrm{g})$ & 0.03527 & ounce, avoirdupois (oz) \\
\hline kilogram $(\mathrm{kg})$ & 2.205 & pound avoirdupois (lb) \\
\hline
\end{tabular}

Temperature in degrees Celsius $\left({ }^{\circ} \mathrm{C}\right)$ may be converted to degrees Fahrenheit $\left({ }^{\circ} \mathrm{F}\right)$ as ${ }^{\circ} \mathrm{F}=\left(1.8 \times{ }^{\circ} \mathrm{C}\right)+32$.

\section{Datum}

Horizontal coordinate information is referenced to the World Geodetic System of 1984 (WGS84). 


\title{
Soil Data for a Vegetation Gradient Located at Bonanza Creek Long Term Ecological Research Site, Interior Alaska
}

By Kristen L. Manies ${ }^{1}$, Jennifer W. Harden ${ }^{1}$, Christopher C. Fuller ${ }^{1}$, Xiaomei Xu², and John P. McGeehin ${ }^{1}$

\begin{abstract}
Boreal soils play an important role in the global carbon cycle owing to the large amount of carbon stored within this northern region. To understand how carbon and nitrogen storage varied among different ecosystems, a vegetation gradient was established in the Bonanza Creek Long Term Ecological Research (LTER) site, located in interior Alaska. The ecosystems represented are a black spruce (Picea mariana)-feather moss (for example, Hylocomium sp.) forest ecosystem, a shrub-dominated ecosystem, a tussock-grass-dominated ecosystem, a sedgedominated ecosystem, and a rich fen ecosystem. Here, we report the physical, chemical, and descriptive properties for the soil cores collected at these sites. These data have been used to calculate carbon and nitrogen accumulation rates on a long-term (decadal and century) basis (Manies and others, in press).
\end{abstract}

\section{Introduction}

High-latitude soils contain approximately 50 percent of the carbon (C) within the global soil C pool (Kasischke, 2000; Tarnocai and others, 2009) and, therefore, play an important role in the global $\mathrm{C}$ cycle. Climate change is expected to impact the boreal region in many ways (Hinzman and others, 2005), which in turn will affect the balance of $\mathrm{C}$ inputs and losses to the soil $\mathrm{C}$ pool. It is also important to understand nitrogen $(\mathrm{N})$ stocks and availability because $\mathrm{N}$ controls many aspects of plant productivity and, therefore, cycling of $\mathrm{C}$ and $\mathrm{N}$ are closely linked (Vile and others, 2014).

To help our understanding of $\mathrm{C}$ and $\mathrm{N}$ stocks in a variety of boreal ecosystems, we measured physical, chemical, and descriptive soil properties in five different ecosystems in interior Alaska. These ecosystems were situated along gradients of soil moisture and dominant vegetation. Factors such as parent material, climate, and topography, which influence soil formation (Jenny, 1941), were consistent along these gradients. We used these data to calculate $\mathrm{C}$ and $\mathrm{N}$ accumulation rates on both decadal and century timescales to determine how the interaction of soil and vegetation influences these rates, and thus, $\mathrm{C}$ and $\mathrm{N}$ storage over time (Manies and others, in press). Findings from this study indicate that the $\mathrm{C}$ and $\mathrm{N}$ dynamics of the

\footnotetext{
${ }^{1}$ U.S. Geological Survey

${ }^{2}$ University of California, Irvine
} 
rich fen are different from the other four ecosystems, likely the result of differences in nutrient cycling and the fire return interval.

\section{Site Description}

Study sites were located on State land adjacent to the U.S. Forest Service Bonanza Creek Experimental Forest, approximately $30 \mathrm{~km}$ southwest of Fairbanks, Alaska, near the floodplain of the Tanana River (lat $64.696^{\circ} \mathrm{N}$., lon $148.321^{\circ} \mathrm{W}$.). These sites were part of the network of sites in the Bonanza Creek Long Term Ecological Research (LTER) program. We studied soils in five ecosystems located along a 300-m transect. Each ecosystem was dominated by a different type of vegetation: (1) a closed-canopy black spruce (Picea mariana) forest with a feather moss (for example, Hylocomium sp.) and ericaceous shrub understory (herein, "black spruce"); (2) a shrub system consisting of willow (Salix sp.) and birch (Betula sp.) with an understory dominated by leatherleaf (Chamaedaphne calyculata) and sparse moss cover (herein, "shrub"); (3) a tussock-grass system dominated by Calamagrostis canadensis with some brown mosses present (herein, "tussock grass"); (4) a peatland dominated by emergent vegetation such as sedges (herein, "sedge"); and (5) a moss-dominated rich fen, consisting of both Sphagnum sp. and brown mosses (herein, "rich fen"). Several publications describe other data obtained from these sites, including ecosystem respiration (McConnell and others, 2013) and microbial abundance (Waldrop and others, 2012).

\section{Soil Sampling}

Three soil cores, encompassing all of the organic soil and extending into the mineral soil below, were collected at each site at randomly selected locations within an area of less than $\sim 10$ $\mathrm{m}^{2}$. Sampling for the black spruce and low shrub site occurred during the summer and samples were obtained using a combination of soil blocks cut to a known volume and a Makita coring device (4.8 cm diameter; Nalder and Wein, 1998). Soil cores from the other three sites were obtained in the spring, when the ground was frozen, using a SIPRE corer $(7.6 \mathrm{~cm}$ diameter; Rand and Mellor, 1985).

Each soil profile was then divided into subsamples representing soil horizons and (or) subsections of different soil horizons. This separation occurred either in the field or, if frozen, in the lab, based on visual factors such as level of decomposition and root abundance. These horizon samples were described using modified soil survey techniques following the U.S. Department of Agriculture's Natural Resource Conservation Service (USDA-NRCS; Soil Survey Staff, 1998) and Canadian (Soil Classification Working Group, 1998) methodologies. We modified horizon codes according to the following scheme:

L Live moss, which is green and generally contains some leaf and needle litter.

D Dead moss, which is undecomposed or slightly decomposed. This horizon is the upper fibric organic horizon that contains more moss than roots. This horizon would be considered an $\mathrm{O}_{\mathrm{i}}$ horizon (U.S. soil system).

F Fibric (Canadian soil system) or fibrous organic horizon, which varies in the degree of decomposition, but in which roots are more abundant than recognizable plant parts. This horizon would be considered an $\mathrm{O}_{\mathrm{i}}$ horizon (U.S. soil system).

M Mesic (Canadian soil system) organic horizon, which is moderately decomposed, with few, if any, recognizable plant parts other than roots. This horizon is generally considered an $\mathrm{O}_{\mathrm{e}}$ horizon (U.S. soil system). 
$\mathrm{H} \quad$ Humic (Canadian soil system) or sapric organic horizon, which is highly decomposed. The soil in this horizon smears when rubbed and contains no recognizable plant parts. The $\mathrm{H}$ horizon is generally considered an $\mathrm{O}_{\mathrm{a}}$ horizon (U.S. soil system).

A Upper mineral soil that forms at the surface or just below organic soil horizons (U.S. and Canadian soil systems), which contains less than 20 -volume-percent organic matter, as judged in the field.

B Lower mineral soil that has formed below an A horizon (U.S. and Canadian soil systems), with little or none of its original lithologic structure.

GR Horizon of matted grass (mostly dead, but some live) at the soil surface.

LT Litter horizon (dead leaves, twigs).

LW Liverwort.

X Unknown (not described).

Each soil horizon was labeled with a four-letter code representing the site, core, and basal depth of the sample. The first two letters of the site code, BZ, denoted that the samples were from the Bonanza Creek LTER. The next third and fourth letters represent the site from which the samples were obtained: BS, black spruce; WB, shrub site; GR, tussock-grass site; EC, sedge site; and MR, rich fen. The BZMR cores were obtained outside a plot that was part of a raised water table experiment (MR signifies manipulated-raised, see Chivers and others, 2009). After the site code, each sample was labeled with a number representing the core/soil-profile, followed by a decimal point and the basal depth of the sample (in centimeters). For example, BZWB 1.8.5 denotes a sample from the shrub site, soil profile 1, with a basal depth of $8.5 \mathrm{~cm}$.

\section{Soil-Sample Preparation and Drying}

All samples were placed on open shelves in an isolated room and allowed to air-dry to a constant weight, as determined by weights measured at least 1 week apart. Temperature during air-drying ranged from $20{ }^{\circ} \mathrm{C}$ to $30{ }^{\circ} \mathrm{C}$. After air-drying, samples were oven-dried for 48 hours in a forced-draft oven. Samples that were classified as organic soil horizons (for example, moss, litter) were oven-dried at $65^{\circ} \mathrm{C}$ to avoid loss or alteration of organic matter by oxidation or decomposition. The remaining samples were oven-dried at $105^{\circ} \mathrm{C}$.

After oven-drying, samples were thoroughly mixed and split into subsamples for analysis and archiving. (Archive fractions of most of the samples described here are available by contacting K. Manies at the U.S. Geological Survey in Menlo Park, Calif.). Samples were then processed in one of two ways, depending on the horizon code. Mineral soil samples were gently crushed using a mortar and pestle, with care to break only aggregates, and then sieved through a 2-mm screen. Soil particles that did not pass through the screen were removed, weighed, and saved separately; soil that passed through the screen was then ground by using a mortar and pestle to pass through a 60 -mesh $(0.246-\mathrm{mm})$ screen. The ground material was mixed and placed in a labeled glass sample bottle for subsequent analyses. Organic samples were weighed, and roots wider than $1 \mathrm{~cm}$ in diameter were removed, weighed, and saved separately. The remaining sample material was then milled in an Udy Corp. Cyclone Sample Mill to pass through a 0.5-mm screen. The milled samples were thoroughly mixed, and a representative sample was placed in a labeled glass sample bottle for analytical chemistry. 


\section{Soil Laboratory Methods}

\section{Total Carbon, Total Nitrogen, $\delta^{13} \mathrm{C}$ Measurements}

We analyzed soil samples for total carbon and nitrogen using a Carlo Erba NA1500 elemental analyzer. Samples were combusted in the presence of excess oxygen. The resulting sample gases were carried by a continuous flow of helium through an oxidation furnace, followed by a reduction furnace, to yield $\mathrm{CO}_{2}, \mathrm{~N}_{2}$, and water vapor. Water was removed by a chemical trap and $\mathrm{CO}_{2}$ and $\mathrm{N}_{2}$ were chromatographically separated before the quantification of $\mathrm{C}$ and $\mathrm{N}$ (Pella, 1990a,b). For samples that also have $\delta^{13} \mathrm{C}$, the elemental analyzer was coupled to a Micromass Optima isotope ratio mass spectrometer (IRMS) in continuous flow mode. For these samples $\mathrm{C}$ and $\mathrm{N}$ were determined by integrating the major ion peaks (mass of 44 for $\mathrm{CO}_{2}$, and mass of 28 for $\mathrm{N}_{2}$ ). For reliable quantification of $\delta^{15} \mathrm{~N}, 15$ to $30 \mu \mathrm{g} \mathrm{N}$ are generally needed and few samples met this criterion. Thus the $\delta^{15} \mathrm{~N}$ data are not reported here; these data are available from the authors by request. The $\delta^{13} \mathrm{C}$ data are reported as deviations in parts per thousand (\%) relative to a standard, here Vienna Pee Dee Belemnite (V-PDB). $\delta^{13} \mathrm{C}$ was calculated using the following equation:

$$
\delta^{13} \mathrm{C} \%=\left(\left(\left({ }^{13} \mathrm{C} \text { sample } /{ }^{12} \mathrm{C} \text { sample }\right) /\left({ }^{13} \mathrm{C} \text { standard } /{ }^{12} \mathrm{C} \text { standard }\right)\right)-1\right) \times 1000
$$

where all $\mathrm{C}$ measured was considered organic $\mathrm{C}$ because carbonates tend not to exist in the study area.

All samples were compared to a main working standard, ethylene diamine tetra-acetic acid (EDTA), for which the $\delta^{13} \mathrm{C}$ value has been determined through a set of international standards. The chemical formula of this compound corresponds to a $\mathrm{C}$ concentration of 41.09 percent and $\mathrm{N}$ concentration of 9.59 percent. Additional working standards were analyzed as samples in all runs to check consistency and overall precision. Peach tree leaves (SRM-1547), issued by the National Institute of Standards and Technology (NIST), were included in runs composed of organic soil. A marine sediment (MESS-1), issued by the Chemistry Division of the Canadian National Research Council, was included in runs composed of mineral soils. Certified values for these standards were obtained from Becker (1990) and Govindaraju (1989), respectively. Average measured values and standard deviations of these working standards are shown in table 1.

Table 1. Statistics of analyses for working standards run on the Carlo Erba 1500, from 2006-2010. [Certified values: MESS-1, 2.99 percent carbon; SRM-1547, 2.94 percent nitrogen. Stdev., standard deviation; N, number of samples]

\begin{tabular}{lcccccc}
\hline \multirow{2}{*}{ Standard } & \multicolumn{3}{c}{ Percent carbon } & \multicolumn{3}{c}{ Percent nitrogen } \\
\cline { 2 - 7 } & Average & Stdev. & N & Average & Stdev. & N \\
\hline MESS-1 & 2.92 & 0.10 & 148 & 0.20 & 0.03 & 148 \\
SRM-1547 & 46.79 & 0.46 & 177 & 2.84 & 0.13 & 177 \\
\hline
\end{tabular}

\section{Radiocarbon Measurements}

A subset of bulk organic matter and picked macrofossil samples were analyzed for radiocarbon $\left({ }^{14} \mathrm{C}\right)$ to evaluate the ages of $\mathrm{C}$ in the soil profile. A little more than half of the samples were processed at the U.S. Geological Survey (USGS) Radiocarbon Laboratory in Reston, Va. and analyzed by accelerator mass spectrometry at the Lawrence Livermore National Laboratory Center for Accelerator Mass Spectrometry (CAMS). The other samples were sent to 
the W.M. Keck Carbon Cycle Accelerator Mass Spectrometry Laboratory at the University of California, Irvine. For all samples, subsamples were combusted at $900{ }^{\circ} \mathrm{C}$ in evacuated, sealed quartz tubes in the presence of cupric oxide $(\mathrm{CuO})$ and silver $(\mathrm{Ag})$ wire. Following cryogenic purification, $\mathrm{CO}_{2}$ was reduced to graphite in a reaction at $500-550{ }^{\circ} \mathrm{C}$ using the sealed-tube $\mathrm{Zn}$ reduction method at the Keck laboratory (Xu and others, 2007) and the $\mathrm{H}_{2}$-reduction method at USGS/CAMS (Vogel and others, 1984). Radiocarbon data are reported as $\Delta^{14} \mathrm{C}$, fraction modern (FM), and radiocarbon age following the conventions of (Stuiver and Polach, 1977). At the Keck laboratory, the reported $\Delta^{14} \mathrm{C}$ values have been corrected for mass-dependent fractionation to a common value of -25 parts per thousand using the simultaneous accelerator mass spectrometry (AMS) $\delta^{13} \mathrm{C}$ measurement. At USGS/CAMS an aliquot of $\mathrm{CO}_{2}$ from the sample combustion was independently analyzed for $\delta^{13} \mathrm{C}$ to correct for fractionation in each sample.

\section{${ }^{210} \mathrm{~Pb},{ }^{226} \mathrm{Ra}$, and ${ }^{137} \mathrm{Cs}$ Measurements}

Dried and ground subsections of cores were analyzed for ${ }^{210} \mathrm{~Pb},{ }^{226} \mathrm{Ra}$, and ${ }^{137} \mathrm{Cs}$ activities as measured by gamma spectrometry. We used a Princeton Gamma HPGe germanium well detector to estimate dry matter accumulation rates for assigning dates to core profiles following methods described in Van Metre and Fuller (2009) and references therein. Briefly, detector efficiency for each isotope was determined using NIST traceable standards $\left({ }^{137} \mathrm{Cs}=\right.$ NBS SRM $4350 \mathrm{~b} ;{ }^{210} \mathrm{~Pb}=$ NBS SRM 4337; ${ }^{226} \mathrm{Ra}=$ NBS SRM 4969). Total ${ }^{210} \mathrm{~Pb}$ activity is the combination of supported ${ }^{210} \mathrm{~Pb}$ (produced within the soil through the decay of ${ }^{226} \mathrm{Ra}$ ) and unsupported ${ }^{210} \mathrm{~Pb}$ (produced in the atmosphere by radon decay and added to the ecosystem through atmospheric deposition). Unsupported ${ }^{210} \mathrm{~Pb}$ was defined as the difference between measured total ${ }^{210} \mathrm{~Pb}$ and ${ }^{226} \mathrm{Ra}$, its long-lived progenitor determined from the activities of ${ }^{214} \mathrm{~Pb}$ and ${ }^{214} \mathrm{Bi}$ gamma-emitting daughters of ${ }^{226} \mathrm{Ra}$. Horizon subsamples from each soil profile were measured until unsupported ${ }^{210} \mathrm{~Pb}$ was no longer detected. Unsupported ${ }^{210} \mathrm{~Pb}$ values were then used to calculate dry mass accumulation rates (MAR, in grams per cubic centimeter per year) for each soil horizon, from which dates of formation were calculated using the Constant Rate of Supply (CRS) model (Appleby and Oldfield, 1978; these dates can be found in the Supplemental section of Manies et al., 2016). Note that for the three grass-soil profiles we did not reach the point at which unsupported ${ }^{210} \mathrm{~Pb}$ could not detected. Because we found ${ }^{210} \mathrm{~Pb}$ in the mineral soil for the grass soil profiles we do not suggest using these data for dating purposes at this site.

${ }^{137} \mathrm{Cs}$, an anthropogenic radionuclide (half-life of 30.1 years), provides a means to constrain sediment accumulation rates and chronology because of its well-known input history from atmospheric fallout from aboveground nuclear weapons testing in the 1950s and first half of the 1960s, with maximum deposition occurring during the years 1963 and 1964 (Callender and Robbins, 1993). Measured ${ }^{137} \mathrm{Cs}$ activities were decay corrected for the period of time between sample collection and analysis. Uncertainty in the measured activity of ${ }^{137} \mathrm{Cs},{ }^{210} \mathrm{~Pb}$, and ${ }^{226} \mathrm{Ra}$ was calculated from the counting error of samples and background spectra; it's reported at the one-standard-deviation level.

\section{Dataset Descriptions}

There are three separate downloadable files containing the soil data collected from the sites described in this report. Appendix 1 lists in detail the data within the following three spreadsheet files: (1) BZ_Gradient_Field, contains field descriptions of the sampled soils, such 
as root abundance, color, and soil texture; (2) BZ_Gradient_Physical contains physical descriptions of the samples, such as volumetric field moisture and bulk density; (3) BZ_Gradient_Chemistry contains elemental C, elemental $\mathrm{N},{ }^{14} \mathrm{C}$, and the radioactive isotope values.

\section{Acknowledgments}

We thank the Bonanza Creek LTER for allowing us to set up these research sites. Their personnel, especially Jamie Hollingsworth, have been instrumental in this research. Merritt Turetsky aided in site identification and characterization; A. David McGuire supported LTER coordination; Lee Pruett, Renata Mendieta, and Pedro Rodriguez assisted with core collection, processing samples, or analyses of core chemistry. We also thank Sara Peek and A.D. McGuire for providing helpful comments on an earlier version of this report. Funding for this work was provided by the National Science Foundation collaborative grant EAR-0630249 and the USGS Global Change program.

\section{References Cited}

Appleby, P.G., and Oldfield, F., 1978, The calculation of Lead-210 dates assuming a constant rate of supply of unsupported ${ }^{210} \mathrm{~Pb}$ to the sediment: Catena, v. 5, no. 1, p. 1-8.

Becker, D.A., 1990, Homogeneity and evaluation of the new NIST leaf certified reference materials, in Zeisler, R., and Guinn, V.P., eds., Proceedings of the International Conference on Nuclear Analytical Methods in the Life Sciences: Gaithersburg, MD, National Institute of Standards, p. 571-577.

Callender, E., and Robbins, J.A., 1993, Transport and accumulation of radionuclides and stable elements in a Missouri River reservoir: Water Resources Research, v. 29, no. 6, p. 1787-1804.

Chivers, M.R., Turetsky, M.R., Waddington, J.M., Harden, J.W., and McGuire, A.D., 2009, Effects of Experimental Water Table and Temperature Manipulations on Ecosystem CO2 Fluxes in an Alaskan Rich Fen: Ecosystems, v. 12, p. 1329-1342.

Damman, A.W.H., and French, T.W., 1987, The ecology of peat bogs of the glaciated northeastern United States-A community profile: U.S. Fish and Wildlife Service Biological Report 85, no 7.16, 100 p.

Govindaraju, K., 1989, Compilation of working value and sample description for 272 geostandards: Geostandards Newsletter, v. 13, p. 1-113.

Hinzman, L.D., Bettez, N.D., Bolton, W.R., Chapin, F.S., Dyurgerov, M.B., Fastie, C.L., Griffith, B., Hollister, R.D., Hope, A., Huntington, H.P., Jensen, A.M., Jia, G.J., Jorgenson, T., Kane, D.L., Klein, D.R., Kofinas, G., Lynch, A.H., Lloyd, A.H., McGuire, A.D., Nelson, F.E., Oechel, W.C., Osterkamp, T.E., Racine, C.H., Romanovsky, V.E., Stone, R.S., Stow, D.A., Sturm, M., Tweedie, C.E., Walker, M.D., Walker, D.A., Webber, P.J., Welker, J.M., Winker, K.S., and Yoshikawa, K., 2005, Evidence and implications of recent climate change in northern Alaska and other arctic regions: Climatic Change, v. 72, p. 251-298.

Jenny, H., 1941, Factors of soil formation; a system of quantitative pedology (1st ed.): New York, McGraw-Hill, 281 p.

Kasischke, E.S., 2000, Boreal ecosystems in the global carbon cycle, in Kasischke, E.S., and Stocks, B.J., eds., Fire, Climate Change, and Carbon Cycling in the Boreal Forest: New York, Springer-Velag, p. 19-30. 
Manies, K.L., Harden, J.W., Fuller, C.C., and Turetsky, M.R., in press, Decadal and long-term boreal soil carbon and nitrogen sequestration rates across a variety of ecosystems:

Biogeosciences.

McConnell, N.A., Turetsky, M.R., McGuire, A.D., Kane, E.S., Waldrop, M.P., and Harden, J.W., 2013, Controls on ecosystem and root respiration across a permafrost and wetland gradient in interior Alaska: Environmental Research Letters, v. 8, no. 4, p. 45029-45029.

Nalder, I.A., and Wein, R.W., 1998, A new forest floor corer for rapid sampling, minimal disturbance and adequate precision: Silva Fennica, v. 32, no. 4, p. 373-381.

Pella, E., 1990a, Elemental organic analysis-Part 1-Historical developments: American Laboratory, v. 22, no. 2, p. 116-125.

Pella, E., 1990b, Elemental organic analyzer-Part 2-State of the art: American Laboratory, v. 22 , no. 12 , p. $28-32$.

Rand, J., and Mellor, M., 1985, Ice-coring augers for shallow depth sampling: U.S. Army Cold Regions Research and Engineering Laboratory CRREL Report 85-21, 27 p.

Soil Classification Working Group, 1998, Canadian System of Soil Classification (3rd ed.): Ontario, National Research Council Canada Research Press, 188 p.

Soil Survey Staff, 1998, Keys to soil taxonomy (8th ed.): Blacksburg, Virginia, Pocahontas Press, $599 \mathrm{p}$.

Stuiver, M., and Polach, H.A., 1977, Discussion reporting of ${ }^{14} \mathrm{C}$ data: Radiocarbon, v. 19, no. 3, p. 355-363.

Tarnocai, C., Canadell, J.G., Schuur, E.A.G., Kuhry, P., Mazhitova, G., and Zimov, S., 2009, Soil organic carbon pools in the northern circumpolar permafrost region: Global Biogeochemical Cycles, v. 23, p. GB2023.

Van Metre, P.C., and Fuller, C.C., 2009, Dual-core mass-balance approach for evaluating mercury and ${ }^{210} \mathrm{~Pb}$ atmospheric fallout and focusing to lakes: Environmental Science \& Technology, v. 43, p. 26-32.

Vile, M.A., Kelman Wieder, R., Živković, T., Scott, K.D., Vitt, D.H., Hartsock, J.A., Iosue, C.L., Quinn, J.C., Petix, M., Fillingim, H.M., Popma, J.M.A., Dynarski, K.A., Jackman, T.R., Albright, C.M., and Wykoff, D.D., 2014, $\mathrm{N}_{2}$-fixation by methanotrophs sustains carbon and nitrogen accumulation in pristine peatlands: Biogeochemistry, v. 121, no. 2, p. 317-328.

Vogel, J.S., Southon, J.R., Nelson, D.E., and Brown, T.A., 1984, Performance of catalytically condensed carbon for use in accelerator mass spectrometry: Nuclear Instruments and Methods in Physics Research Section B: Beam Interactions with Materials and Atoms, v. 5, no. 2, p. 289-293.

Waldrop, M.P., Harden, J.W., Turetsky, M.R., Petersen, D.G., McGuire, A.D., Briones, M.J.I., Churchill, A.C., Doctor, D.H., and Pruett, L.E., 2012, Bacterial and enchytraeid abundance accelerate soil carbon turnover along a lowland vegetation gradient in interior Alaska: Soil Biology \& Biochemistry, v. 50, p. 188-198.

Xu, X., Trumbore, S.E., Zheng, S., Southon, J.R., McDuffee, K.E., Luttgen, M., and Lui, J.C., 2007, Modifying a sealed tube zinc reduction method for preparation of AMS graphite targets: Reducing background and attaining high precision: Nuclear Instruments and Methods in Physics Research Section B: Beam Interactions with Materials and Atoms, v. 259, no. 1, p. 320-329. 


\section{Appendix 1. Data File Descriptions}

The data files are available online only as Excel (.xlsx) spreadsheets. The zip file (.zip) containing these files is available at http://dx.doi.org/10.3133/ofr20161034. The content of these files is described in this appendix.

\section{Bonanza_Gradient_Field}

This file contains the field descriptions of the sampled soils. Units for each column are given on row 2 of the file. This file includes the following columns:

\begin{tabular}{|c|c|}
\hline Sample ID & $\begin{array}{l}\text { Sample identification: The first two letters in the sample ID represent the area } \\
\text { of study, Bonanza Creek LTER (BZ). The next two letters represent the } \\
\text { ecosystem (BS, black spruce; WB, shrub; GR, tussock grass; EC, sedge; } \\
\text { MR, rich fen). Then there is a space. The number that follows indicates the } \\
\text { sample number. A decimal point separates the sample number from the } \\
\text { basal depth of the sample (in centimeters). }\end{array}$ \\
\hline Depth & Indicates the basal depth, in centimeters, of sampling increment. \\
\hline Field horizon code & $\begin{array}{l}\text { Horizon type of the sample, as defined in the field. L, live moss; D, dead } \\
\text { moss; F, fibric organic matter (OM); M, mesic OM; H, humic OM; A, A } \\
\text { mineral soil horizon; B, B mineral soil horizon; GR, grass; LT, litter; LW, } \\
\text { liverwort; X, unknown horizon. For more information about these horizon } \\
\text { types see the Soil Sampling section of this report. }\end{array}$ \\
\hline Sample description & Brief description of the sample. \\
\hline Roots & $\begin{array}{l}\text { Root abundance and size using conventions of USDA-NRCS (Soil Survey } \\
\text { Staff, 1998). }\end{array}$ \\
\hline Lab pH & $\begin{array}{l}\mathrm{pH} \text { value of mineral soil measured in the laboratory. Deionized water was } \\
\text { added to create a soil slurry ( } 50 \text { percent soil, } 50 \text { percent water) prior to } \\
\text { measurement. }\end{array}$ \\
\hline Munsell moist color & $\begin{array}{l}\text { Munsell color value according to the Munsell Soil Color Chart, measured on } \\
\text { moist soil }\end{array}$ \\
\hline Von Post or texture & $\begin{array}{l}\text { If organic soil, the classification using the von Post scale of humification } \\
\text { (Damman and French, 1987). If mineral soil, the soil texture class as } \\
\text { described in the field, following conventions of USDA-NRCS (Soil Survey } \\
\text { Staff, 1998). }\end{array}$ \\
\hline Height above mineral & $\begin{array}{l}\text { Height of each basal depth above the mineral soil boundary. Therefore, the } \\
\text { bottom organic layer equals zero and mineral horizons are negative } \\
\text { numbers. }\end{array}$ \\
\hline
\end{tabular}




\section{Bonanza_Gradient_Physical}

This file contains physical data such as bulk density and volumetric moisture content. Units for each column are given on row two of the file. Column definitions are as follows:

\begin{tabular}{|c|c|}
\hline Sample ID & $\begin{array}{l}\text { Sample identification: The first two letters in the sample ID represent the area } \\
\text { of study, Bonanza Creek LTER (BZ). The next two letters represent the } \\
\text { ecosystem (BS, black spruce; WB, shrub; GR, tussock grass; EC, sedge; } \\
\text { MR, rich fen). Then there is a space. The number that follows indicates the } \\
\text { sample number. A decimal point separates the sample number from the } \\
\text { basal depth of the sample (in centimeters). }\end{array}$ \\
\hline Depth & Indicates the basal depth, in centimeters, of sampling increment. \\
\hline Field horizon code & $\begin{array}{l}\text { Horizon type of the sample, as defined in the field. L, live moss; D, dead } \\
\text { moss; F, fibric organic matter (OM); M, mesic OM; H, humic OM; A, A } \\
\text { mineral soil horizon; B, B mineral soil horizon; GR, grass; LT, litter; LW, } \\
\text { liverwort; X, unknown horizon. For more information about these horizon } \\
\text { types see the Soil Sampling section of this report. }\end{array}$ \\
\hline Sample description & Brief description of the sample. \\
\hline Date sampled & Date the sample was taken (month/day/year). \\
\hline Thickness & Thickness of soil horizon. \\
\hline$>2 \mathrm{~mm}$ in sample & $\begin{array}{l}\text { Dry weight percent of soil particles not passing through a } 2 \mathrm{~mm} \text { sieve after } \\
\text { gentle crushing. }\end{array}$ \\
\hline$>1 \mathrm{~cm}$ in sample & Dry weight percent of roots larger than $1 \mathrm{~cm}$ in diameter in the sample. \\
\hline Bulk density $(<2 \mathrm{~mm})$ & $\begin{array}{l}\text { Grams of oven-dried soil per cubic centimeter, with soil particles greater than } \\
2 \mathrm{~mm} \text { and roots greater that } 1 \mathrm{~cm} \text { diameter removed. }\end{array}$ \\
\hline Bulk density & $\begin{array}{l}\text { Grams of oven-dried soil per cubic centimeter for the entire soil sample with } \\
\text { no fractions excluded. Calculated similarly to "Bulk density }(<2 \mathrm{~mm}) \text { " } \\
\text { except the weight of particles greater than } 2 \mathrm{~mm} \text { and roots greater than } 1 \\
\text { cm diameter have been included. }\end{array}$ \\
\hline Volumetric field moisture (OD) & $\begin{array}{l}\text { The percentage of water in the sample, by volume, of the oven dried (OD) } \\
\text { sample. }\end{array}$ \\
\hline $\begin{array}{l}\text { Convert from AD to OD bulk } \\
\text { density }\end{array}$ & $\begin{array}{l}\text { Moisture remaining in a sample after air-drying (AD) to constant weight as } \\
\text { determined by subsequently oven-drying (OD) the sample. Bulk density, on } \\
\text { an air-dried basis, equals Bulk density }{ }_{\text {oven dry }} /(1-(\text { Convert from AD to OD } \\
\text { bulk density/100)). }\end{array}$ \\
\hline
\end{tabular}




\section{Bonanza_Gradient_Chemistry}

This file contains analytical data for the samples. Units for each column are given on row 2 of the file. Column definitions are as follows:

\begin{tabular}{|c|c|}
\hline Sample ID & $\begin{array}{l}\text { Sample identification: The first two letters in the sample ID represent the } \\
\text { area of study, Bonanza Creek LTER (BZ). The next two letters represent } \\
\text { the ecosystem (BS, black spruce; WB, shrub; GR, tussock grass; EC, } \\
\text { sedge; MR, rich fen). Then there is a space. The number that follows } \\
\text { indicates the sample number. A decimal point separates the sample } \\
\text { number from the basal depth of the sample (in centimeters). }\end{array}$ \\
\hline Depth & Indicates the basal depth, in centimeters, of sampling increment. \\
\hline Field horizon code & $\begin{array}{l}\text { Horizon type of the sample, as defined in the field. L, live moss; D, dead } \\
\text { moss; F, fibric organic matter (OM); M, mesic OM; H, humic OM; A, A } \\
\text { mineral soil horizon; B, B mineral soil horizon; GR, grass; LT, litter; LW, } \\
\text { liverwort; X, unknown horizon. For more information about these horizon } \\
\text { types see the Soil Sampling section of this report. }\end{array}$ \\
\hline Sample description & Brief description of the sample. \\
\hline Carbon & $\begin{array}{l}\text { Percentage by weight of total carbon }(\mathrm{C}) \text { in an oven-dried soil sample with } \\
\text { material greater than } 2 \mathrm{~mm} \text { or } 1 \mathrm{~cm} \text { diameter removed. }\end{array}$ \\
\hline Nitrogen & $\begin{array}{l}\text { Percentage by weight of total nitrogen }(\mathrm{N}) \text { in an oven-dried soil sample with } \\
\text { material greater than } 2 \mathrm{~mm} \text { or } 1 \mathrm{~cm} \text { diameter removed. }\end{array}$ \\
\hline$\delta^{13} \mathrm{C}$ & $\begin{array}{l}\text { Stable isotope signature of oven-dried sample with material }>2 \mathrm{~mm} \text { or } 1 \mathrm{~cm} \\
\text { diameter removed. }\end{array}$ \\
\hline LOI & $\begin{array}{l}\text { Loss-on-ignition value of oven-dried sample with material }>2 \mathrm{~mm} \text { or } 1 \mathrm{~cm} \\
\text { diameter removed. }\end{array}$ \\
\hline${ }^{137} \mathrm{Cs}$ & Amount of ${ }^{137} \mathrm{Cs}$ measured in the sample. \\
\hline${ }^{137}$ Cs error & Laboratory error associated with the ${ }^{137} \mathrm{Cs}$ measurement. \\
\hline${ }^{210} \mathrm{~Pb}$ & Amount of ${ }^{210} \mathrm{~Pb}$ measured in the sample. \\
\hline${ }^{210} \mathrm{~Pb}$ error & Laboratory error associated with the ${ }^{210} \mathrm{~Pb}$ measurement. \\
\hline${ }^{226} \mathrm{Ra}$ & Amount of ${ }^{226} \mathrm{Ra}$ measured in the sample. \\
\hline${ }^{226} \mathrm{Ra}$ & Laboratory error associated with the ${ }^{226} \mathrm{Ra}$ measurement. \\
\hline Bulk sample: lab number & $\begin{array}{l}\text { Laboratory number for the sample when submitted for } 14 \mathrm{C} \text { values. Sample } \\
\text { numbers in the form of WW\#\#\#\# are from Lawrence Livermore, ones in } \\
\text { the form of UCIT\#\#\#\# are from UC Irvine. }\end{array}$ \\
\hline Bulk sample: fraction modern & Fraction modern for the bulk soil sample. \\
\hline Bulk sample: \pm fraction modern & $\begin{array}{l}\text { Analytical error associated with the fraction modern value for the bulk soil } \\
\text { sample. }\end{array}$ \\
\hline Bulk sample: $\Delta^{14} \mathrm{C}$ & $\Delta^{14} \mathrm{C}$ value (\%) for the bulk soil sample. \\
\hline Bulk sample: $\pm \Delta^{14} \mathrm{C}$ & Analytical error of $\Delta{ }^{14} \mathrm{C}$ value (\%) for the bulk soil sample. \\
\hline Bulk sample: ${ }^{14} \mathrm{C}$ age & Radiocarbon age (years, uncorrected) of the bulk soil sample. \\
\hline Bulk sample: $\pm{ }^{14} \mathrm{C}$ age & Analytical error of radiocarbon age (years) for the bulk soil sample. \\
\hline Picked material: lab number & $\begin{array}{l}\text { Laboratory number for the sample when submitted for 14C values. Sample } \\
\text { numbers in the form of WW\#\#\#\# are from Lawrence Livermore, ones in } \\
\text { the form of UCIT\#\#\#\# are from UC Irvine. }\end{array}$ \\
\hline Picked material: fraction modern & Fraction modern for picked material. \\
\hline Picked material: \pm fraction modern & Analytical error of the fraction modern value for picked material. \\
\hline Picked material: $\Delta^{14} \mathrm{C}$ & $\Delta{ }^{14} \mathrm{C}$ value for picked material. \\
\hline Picked material: $\pm \Delta^{14} \mathrm{C}$ & Analytical error of $\Delta{ }^{14} \mathrm{C}$ value for picked material. \\
\hline Picked material: ${ }^{14} \mathrm{C}$ age & Radiocarbon age (uncorrected) of picked material. \\
\hline Picked material: $\pm{ }^{14} \mathrm{C}$ age & Analytical error of radiocarbon age for picked material. \\
\hline Notes & $\begin{array}{l}\text { Information regarding what type of material was picked and submitted for } \\
{ }^{14} \mathrm{C} \text { analysis. }\end{array}$ \\
\hline
\end{tabular}



ISSN 2331-1258 (online)

http://dx.doi.org/10.3133/

ofr20161034 